\section{Sir Robert Mond's Bequest to the British Museum}

Ax the meeting of the Trustees of the British Museum on May 13 the receipt was reported under the terms of the will of the late Sir Robert Mond of the biggest and most important collection of Egyptian antiquities of all periods that has reached the Museum for at least fifty years. The bequest includes 260 objects, which fill gaps in the collections in every class of Egyptian art. Among the sculptures are an Eighteenth Dynasty three-quarter size head and shoulders of an official, a number of ushabtis, among which is one contained in a nest of model coffins, also belonging to the Eighteenth Dynasty, and a statuette in steatite, which is especially fine, of an official, Sunuri, of the Nineteenth Dynasty. Of the bronzes, one of the most remarkable, as well as one of the best, is an axe-head of the Eighteenth Dynasty, obviously intended for ceremonial or ornamental use. It is in the Syrian style, and has inserted within its margin an extremely beautiful group of a dog bringing down a wild goat. The bequest also contains jewelry, scarabs, pottery, copies of the Book of the Dead, and some examples of the now well-known Roman portraits from the Fayum. Of these, one represents a woman with a gold tiara and necklace, and is most vivid and convincing. Among other accessions to the Egyptian collections reported is an open-work scarab in gold of the Middle Kingdom c. $2700-2300$ B.c.), which is of a type new to the Museum. It has been given by Prof. P. E. Newberry. Two fragments of Anglo-Saxon sculpture, the first to be received for some years, have been presented by Mrs. G. W. Haswell and Mr. F. T. Haswell. Both pieces are in red sandstone, and are North Mercian work of the ninth or tenth century A.D. from Chester or its neighbourhood. The finer fragment is ornamented on both faces and on the sides and end with an interlaced pattern of animals and scrolls, the chief figure being a large lion of barbaric design.

\section{Archæology and A.R.P.}

A DISCOVERY of considerable interest to archæologists has been made at Canterbury in the course of excavations for an A.R.P. Control Centre at the rear of the municipal buildings on the Dane John. A Roman pottery kiln has been found in the natural clay at a depth of about seven feet below the present ground level. Associated with the kiln were a number of potsherds, together with some forty to fifty of the tops of jars and other vessels in a variety of shapes and sizes. Among fragments of Belgic and Samian ware is a base which bears the name of the potter, 'Pavlim'. A trench running across the excavation, and extending some four to five feet into the clay, is, it is presumed, the source of the clay from which pots were made. A.R.P. excavation is also responsible for a find, in certain respects of even greater interest, which is reported from Bartonon-Humber, Lincolnshire (The Times, May 15). Here human skeletons have been found in association with a number of objects, which are held to be AngloSaxon of the fifth or sixth century A.D. They have been examined by Mr. T. Sheppard, of the Hull
Municipal Museum. Among the associated antiquities are a large hanging bowl of bronze, with three escutcheons for attachment, probably originally used in the Saxon church of St. Peter, a cylindrical bronze box, with a lid highly decorated, used by Saxon women for needle and thread and having an attachment for suspension to the waist, and a large decorated gold bead. The find of the bronze bowl is of particular interest, as it belongs, presumably, to a class of antiquity which has been made the subject of study by Mr. T. D. Kendrick of the British Museum, and has been shown by him to be of British (Celtic) derivation.

\section{Culture of Pre-Industrial Britain}

Sir CyrIL Fox, director of the National Museum of Wales, delivered the annual Im Thurn Memorial Lecture to the Scottish Anthropological and Folklore Society on April 17. Sir Cyril emphasized the urgent need of making an adequate record of the cultures of Britain of the pre-Industrial Revolution era, cultures which survive more or less intact in outlying districts, and the material remains of which are still very widely distributed. He had cast his title, "A Field Museum To-morrow: What's to do To-day ?", into a colloquial form to emphasize his view that the matter concerned the man-in-the-street in every geographical or political region in Britain. The collection of material for the future national open-air museums should be carried out on rigidly scientific lines, special attention being devoted to things related to life and work on the land. We need the furniture of farmhouse and cottages of every century from the sixteenth; the carts, tools and implements used on the farms: tools used in, and products of, rural industries. Techniques of farm and house building should be recorded and photographed; farm lay-outs should be planned. Only adequately provenanced objects should be collected ; only so can we hope to map, ultimately, the cultural regions of pre-industrial Britain. We want to know whether the boundaries of these regions are political or economic. If political, do they go back to the Heptarchy in southern Britain? Outside a few museums, the fate of British folk-material is a sad one-torn from its environment, it is regarded as 'old world' and 'quaint', collected by those from whom its real interest and importance as a manifestation of a once vigorous culture are hidden. How many collectors trouble to record the exact provenance of their specimens?

\section{Exhibit of Historic Aeroplanes}

A SPECIAL exhibit of aeroplanes representing an epoch in the history of aviation has been arranged in No. 1 Gallery at the Science Museum, South Kensington, and will be on view for about six weeks. The machines have been lent by Mr. R. G. J. Nash, who has carefully restored them to their original condition and has flown them on various occasions. The exhibit is an interesting supplement to the permanent National Aeronautical Collection which contains such historic machines as the original Wright 